\title{
Portrety
}

\section{Ryszard Löw jakiego (nie) znamy}

Łukasz Tomasz Sroka

TEKSTY DRUGIE 2019, NR 4, S. 266-278

DOI: $10.18318 /$ td.2019.4.16 | ORCID: 0000-0002-9422-2426
Artykuł napisany w ramach

realizacji projektu

"Supremacja polityczna

Habsburgów a proces

kształtowania się elit

galicyjskich wXIX wieku",

finansowanego ze środków

Narodowego Centrum

Nauki przyznanych na

podstawie umowy numer

UMO-2015/19/B/HS3/02116.
D yszard Löw (ur. w 1931 roku w Krakowie) ${ }^{1}$ zajął stałe 1 i bardzo ważne miejsce w szeroko rozumianej nauce i kulturze Polski i Izraela. W tym kontekście wydawać by się mogło, daremny to trud, przypominanie o nim. Istnieje jednak duże niebezpieczeństwo, że nasza wiedza o Ryszardzie Löwie zostanie zredukowana głównie do ogólnych haseł, co do których istnieje powszechna zgodność. Możemy więc powtarzać, że mamy do czynienia z wybitnym polskim i izraelskim publicystą, bibliografem, wydawcą, krytykiem literackim, propagatorem kultury oraz wytrawnym badaczem: wzajemnego oddziaływania literatury polskiej i hebrajskiej, zaangażowania Żydów w działalność wydawniczą oraz historii antykwariuszy

1 W niniejszym tekście przyjąłem pisownię nazwiska "Löw”, nie zaś "Loew". Sam Ryszard Löw posługuje się właśnie tą pierwszą wersją, druga pojawiła się dlatego, że w minionych dekadach część drukarni w Izraelu nie dysponowała czcionkami zawierającymi literę "ö", inni zaczęli też powielać wprowadzoną w związku z tym pisownię "Loew". Pozostawiam pisownię "Loew" tam, gdzie występuje ona w cudzym tekście lub w notce bibliograficznej, by nie naruszać ich oryginalnego charakteru.

\section{Łukasz Tomasz}

Sroka - dr hab. nauk humanistycznych w zakresie historii, profesor Uniwersytetu Pedagogicznego w Krakowie, infobroker. Dyrektor Instytutu Historii i Archiwistyki tegoż Uniwersytetu. Badania naukowe koncentruje na historii i kulturze Żydów w XIX i XX wieku, historii Izraela oraz historii Galicji. Ostatnio opublikował: In the Light of Vienna. Jews in Lviv - between Tradition and Modernisation (1867-1914), Berlin 2018 oraz Demokracja izraelska (wspólnie z K. Chaczko i A. Skorkiem, z przedmową Szewacha Weissa), Warszawa 2018. 
żydowskich w Polsce. Najwyższy szacunek, którym cieszy się Löw w środowisku uczonych, nie przekłada się jednak na odpowiednio wysoką częstotliwość odwoływania się do jego prac i cytowania ich. W niewystarczającym stopniu korzystamy z jego doświadczenia i wiedzy, którą przekazał nam w swoich publikacjach (a uwaga ta dotyczy zwłaszcza najmłodszego pokolenia badaczy). Ten stan rzeczy wynika z różnych przesłanek. Otóż Löw uprawia naukę w sposób interdyscyplinarny - przypomnijmy, że ma za sobą studia historyczne i ekonomiczne, które odbył w Krakowie, Paryżu i Tel Awiwie. Taka postawa bywa chwalona, a zarazem powoduje, że badacz może funkcjonować w różnych środowiskach naukowych, ale raczej na ich obrzeżach niż w centrum.

Kłopot z dopasowaniem Löwa w (jedno) konkretne miejsce odnosi się zresztą nie tylko do bibliotecznych szufladek, pośród których jego twórczość bywa rozproszona pod znakiem historii, historii literatury, judaistyki i jeszcze innych dyscyplin. Podobnież ma się rzecz z kwestią adresów wydawniczych. Dorobek piśmienniczy Löwa współtworzy dziś kanon prac z zakresu historii stosunków polsko-żydowskich i polsko-izraelskich w literaturze, ponieważ w swojej dziedzinie jest najlepszy. W tym kontekście przede wszystkim należy wymienić jego prace: Adolf Rudnicki w literaturze hebrajskiej², Brzozowski wśród lektur syjonistycznych ${ }^{3}$, Hebrajska obecność Juliana Tuwima. Szkice bibliograficzne ${ }^{4}$, Hebrajska recepcja twórczości Stowackiego ${ }^{5}$, Hebrajskie dzieje Sienkiewicza ${ }^{6}$, Literatura polska w przekładach hebrajskich ${ }^{7}$, Mickiewicz w kręgu hebrajskim ${ }^{8}$, Prus w domenie

2 "Ruch Literacki" R. XXX, 1989, Z. 3 (174), s. 251-255.

3 "Teksty Drugie" 2003 nr 6, s. 157-166.

4 Wydawnictwo Hasefer, Tel Awiw 1993. Zob. również: R. Löw Jerozolimski przyjaciel Tuwima. Leib Jaffe w kręgu polskim. Spotkanie z Tuwimem, "Zeszyty Literackie” 1992 nr 38, s. 108-115; tegoż "My Żydzi polscy..." w hebrajskiej opinii literackiej, "Literatura na Świecie” 1992 nr 5/6, s. $372-375$.

5 Artykuł opublikowany w: Podróże po historii. Studia z dziejów kultury i polityki europejskiej ofiarowane profesorowi Stanisławowi Grzybowskiemu, red. F. Leśniak, Wydawnictwo Naukowe Akademii Pedagogicznej, Kraków 2000, s. 190-201. Zob. również: tegoż Słowacki w przekładach hebrajskich, "Dekada Literacka” 1999 nr 11/12, s. 20-21; praca ukazała się również w: „Słowo Żydowskie - Dos Jidisze Wort" 1999 nr 21, s. 17, 21.

6 "Literatura na Świecie" 1992 nr 5/6, s. 380-387. Zob. również: tegoż Sienkiewicz w przekładach hebrajskich, "Zdanie” 1989 nr 5, s. 59-60.

7 "Archiwum Emigracji. Studia - Szkice - Dokumenty" R. 2000, Z. 3, s. 93-101. Zob. również: tegoż Literatura polska w przekładach hebrajskich, "Twórczość" 2000 nr 4, s. 125-131.

8 "Kontury” 1999 nr X, s. 119-127; "Więź" 1999 nr 1, s. 75-84. Zob. również: tegoż Mickiewicz w świecie hebrajskim, "Blok-Notes. Muzeum Literatury im. Adama Mickiewicza” 1999 nr 12/13, 
hebrajskiej (Rekonesans) ${ }^{9}$, Rozpoznania. Szkice literackie ${ }^{10}$, „Trylogia” w oczach krytyki hebrajskiej" ${ }^{11}$ Wyspiański po hebrajsku ${ }^{12}, Z$ dziejów Reymonta w literaturze hebrajskiej: „Chłopi" ${ }^{\prime \prime}$, Znaki obecności. O polsko-hebrajskich i polsko-żydowskich zwiazkach literackich ${ }^{14}$ i Żeromski w literaturze hebrajskiej ${ }^{15}$. Tego rodzaju publikacje, co: Pod znakiem starych foliantów. Cztery szkice o sprawach żydowskich $i$ ksią̇kowych ${ }^{16}$, wyznaczają nasz poziom wiedzy na temat żydowskiego handlu książką. Notabene sam autor szczególną sympatią darzy książkę Pod znakiem starych foliantów..., ponieważ wywołała ona najżywsze poruszenie wśród czytelników i stała się nieformalnym podręcznikiem dla badaczy i uczestników krakowskiego rynku księgarskiego i antykwarycznego; tymczasem Löw, mimo że w 1952 roku na stałe zamieszkał w Tel Awiwie, to nigdy nie przestał darzyć sentymentem rodzinnego Krakowa ${ }^{17}$. Odrębny charakter ma jego artykuł poświęcony białostockim korzeniom „Habimy” - Teatru Narodowego Izraela ${ }^{18}$. Waga tego tekstu jest bardzo duża, ponieważ wiele publikacji międzynarodowych umiejscawia początki „Habimy” w Moskwie w okresie I wojny światowej. Natomiast Löw opisał „Habimę Pierwszą", grupę teatralną zebraną przez Nachuma Dawida Cemacha (1887-1939) w Białymstoku jeszcze przed wybuchem Wielkiej Wojny. Spod jego pióra wyszły również wyśmienite przedmowy i posłowia

s. 271-277; praca ukazała się także w: "Słowo Żydowskie - Dos Jidisze Wort” 1998 nr 22, s. 14-15; "Universitas" 1999 nr 24, s. 30-32; tegoż Pan Tadeusz po hebrajsku (Dzieje przekładu, wydania i recepcji krytycznej), "Literatura na Świecie" 1998 nr 9, s. 299-313.

"Akcent" 1997 nr 4, s. 190-192.

Wydawnictwo Księgarnia Akademicka, Kraków 1998.

"Pamiętnik Literacki” 2000 nr 4, s. 181-186.

„Kraków" 1989 nr 4, S. 21-22.

„Teksty Drugie" 2000 nr 1/2, s. 121-129.

Wydawnictwo Towarzystwo Autorów i Wydawców Prac Naukowych "Universitas”, Kraków 1995.

"Kontury” 1994 nr V, s. 112-117. Zob. również: tegoż O Żeromskim w Izraelu, „Wiadomości” 1976 $\mathrm{nr} 1564$.

Universitas, Kraków 1993.

Rozmowa Ł.T. Sroki z Ryszardem Löwem, przeprowadzona w Tel Awiwie, 22.11.2016 roku.

R. Löw Habima Pierwsza. Narodziny teatru hebrajskiego w Białymstoku, w: Żydzi wschodniej Polski, seria III: Kobieta żydowska, red. nauk. A. Janicka, J. Ławski, B. Olech, Alter Studio, Białystok 2015, s. 479-486. 
do (najczęściej) polskojęzycznych prac literackich i wspomnieniowych drukowanych w Izraelu ${ }^{19}$.

Rzecz w tym, że na pokaźną część dorobku Löwa składają się różne pod względem gatunkowym prace, które ukazały się w oddalonych od siebie miejscach, czy to w Wielkiej Brytanii (londyńskie "Wiadomości”), czy w Izraelu („Nowiny Kurier”, „Od Nowa”), czy w Polsce („Tygodnik Powszechny”, „Kraków. Magazyn Kulturalny"). Nadto znajdziemy twórczość Löwa w profesjonalnych, ale skądinąd niszowych pismach, by wspomnieć tylko „Ruch Literacki” i „Lithuanię". Publikował w paryskich „Zeszytach Historycznych” i „Kulturze”. Obydwa pisma odegrały doniosłą rolę w polskiej nauce, kulturze i polityce, lecz dzisiaj sytuują się poza głównym nurtem polskiego czasopiśmiennictwa naukowego (głównie wskutek tego, że przestały się ukazywać). Przekazywał też swoje teksty pismom wspaniałym pod względem poziomu merytorycznego, ale efemerycznym - jak „Masada” (ukazał się zaledwie jeden numer tego pisma, które w założeniu miało być kwartalnikiem) ${ }^{20}$. Na tym tle wyróżnia się np. „Biuletyn Żydowskiego Instytutu Historycznego w Polsce” (obecnie „Kwartalnik Historii Żydów”), gdyż jest to pismo, do którego historycy - także ci młodszego pokolenia - sięgają często ${ }^{21}$. Z tego powodu wielu badaczy spotyka się z problemem ogarnięcia całej spuścizny Löwa. Konsekwencją jest to, że jego twórczość znamy (tak nam się przynajmniej wydaje), ale tylko szczątkowo.

W kontekście poruszonych wcześniej problemów niezwykle cenna jest książka Ryszarda Löwa zatytułowana: Literackie podsumowania.Polsko-hebrajskie

19 Zob. R. Löw Przedmowa, w: A. Ziemny Notesy adresowe, przeł. M. Akavia, A. Brauner, EKED, Tel Awiw 1989; tegoż Przedmowa, w: Ł. Gliksman Wiersze zebrane, "Kontury”, Tel Awiw 2004, s. 3-11; tegoż Przedmowa, w: Matka w mroku i inne wiersze, wydanie dwujęzyczne polsko-hebrajskie, przeł. na hebrajski Sz. Raczyńska, "Kontury”, Tel Awiw 1995, s. 103-98; tegoż Posłowie, w: Bialik. Czernichowski. Wiersze, przeł. Sz. Raczyńska, Notza Vakeset, Tel Awiw 1988, s. 42-46; tegoż Posłowie, w: B. Leśmian Samotność i inne wiersze, przeł. Sz. Raczyńska, A. Brauner, Chana Szamir, Tel Awiw 1992, s. 85-79; tegoż Słowo o autorce, w: Ł. Gliksman Wczoraj i inne wiersze, w oryg. i przekł. na hebr. I. Amiel, Sz. Raczyńskiej, "Kontury”, Tel Awiw 1993, s. 4-5.

R. Löw Przekłady hebrajskie z literatury polskiej, „Masada” jesień 1991, s. 221-226. Por. S. Majdosz "Masada" Bogdana Wojdowskiego, w: Prasa Żydów polskich. Od przeszłości do teraźniejszości, red. A. Karczewska, S.J. Żurek, Towarzystwo Naukowe Katolickiego Uniwersytetu Lubelskiego Jana Pawła II, Wydawnictwo KUL, Lublin 2016, S. 127-138. dowskiego Instytutu Historycznego w Polsce" 1991 nr 3 (159), s. 71-81; O żydowskich antykwariuszach księgarskich w Krakowie, "Biuletyn Żydowskiego Instytutu Historycznego" 1992 nr 2/3, s. 91-106. 
ipolsko-izraelskie 22. Zostały w niej zebrane wybrane jego artykuły, które wcześniej ukazały się w pismach: „Kontury”, „Nowiny Kurier”, „Teksty Drugie”, "Więź" i innych. Książkę zredagowali Michał Siedlecki i Jarosław Ławski. Opatrzono ją cennym posłowiem autorstwa Barbary Olech. W roli recenzentów wystąpili uznani profesorowie: Dariusz K. Sikorski i Michał Głowiński. Książkę tę wydano staraniem Katedry Badań Filologicznych „Wschód - Zachód" Wydziału Filologicznego Uniwersytetu w Białymstoku. Aczkolwiek także ta pozycja wydawnicza nie spotkała się z należnym jej odzewem. Stało się tak z różnych powodów, do kluczowych z nich zaliczymy bez wątpienia brak jakiejkolwiek reklamy i medialnego nagłośnienia. Wymienieni tutaj naukowcy wykazali się nie lada pracowitością, ale wydawca nie zechciał jej odpowiednio docenić.

Właściwe jest postawienie pytania o źródła zainteresowań i sukcesów naukowych Löwa. Przyszedł na świat w rodzinie inteligenckiej Józefa i Dory z Heckerów. Jego ojciec zajmował stanowisko dyrektora handlowego w renomowanej firmie farmaceutycznej „Dr A. Wander Spółka Akcyjna”. Tę mieszczącą się na skraju ówczesnego Krakowa firmę w 1931 roku założył szwajcarski inwestor. Wydaje się jednak, że pierwszorzędną rolę w zaszczepieniu u niego zainteresowań intelektualnych odegrała matka, świetnie wykształcona, energiczna i poważana w środowisku inteligenckim polonistka ${ }^{23}$.W ocenie Barbary Olech: „była krakowianką, nie znającą już języka żydowskiego. Ukończyła polonistykę na Uniwersytecie Jagiellońskim. Zaraziła swego jedynaka miłością do książek, literatury i kultury polskiej"24. Poznając warsztat naukowy Löwa, odkrywamy metodę pracy właściwą dla uczonych pielęgnujących najpiękniejsze, jeszcze przedwojenne tradycje polskiej i żydowskiej humanistyki. Należy do niej staranne gromadzenie własnej biblioteki, na którą składają się prace z zakresu prowadzonych przez siebie badań i pokrewne ${ }^{25}$. W czasach,

22 R. Löw Literackie podsumowania, polsko-hebrajskie, polsko-izraelskie, red. tomu, oprac. M. Siedlecki i J. Ławski, posł. B. Olech, Przełomy/Pogranicza. Studia Literackie IX, Zakład Badań Interdyscyplinarnych i Porównawczych „Wschód - Zachód”. Wydział Filologiczny UwB, Białystok 2014. Recenzję tej książki opublikowałem na łamach pisma "Scripta Judaica Cracoviensia” 2016 vol. 14, s. 177-179.

23 Rozmowa Ł.T. Sroki z prof. Stanisławem Grzybowskim, przeprowadzona w Krakowie dn. 14.12.2016r.

24 B. Olech Posłowie. Ryszard Löw - Krakowianin z Tel Awiwu, w: R. Löw Literackie podsumowania, polsko-hebrajskie, polsko-izraelskie, s. 230.

25 R. Löw swój księgozbiór zapisał w testamencie Bibliotece Uniwersyteckiej w Białymstoku. Rozmowa Ł.T. Sroki z Ryszardem Löwem, przeprowadzona w Tel Awiwie 22.11.2016 roku. Löw 
gdy nie było jeszcze Internetu, monitorowanie rynku wydawniczego bazowało w dużej mierze na przyjacielskich kontaktach i wzajemnej wymianie publikacji. W tym względzie mógł liczyć na kilku wypróbowanych przyjaciół, a pośród nich miejsce wyjątkowe zajęli krakowscy profesorowie: Stanisław Grzybowski (ur. 1930), z którym Löw zawiązał serdeczną przyjaźń już w okresie szkolnym, i Henryk Markiewicz (1922-2013). Dzięki nim, choć mieszkał w Izraelu, nie stracił orientacji w polskich nowościach wydawniczych (było to tym cenniejsze, że po wojnie sześciodniowej Polska zerwała stosunki dyplomatyczne z Izraelem). Dlatego mógł informować czytelników w Izraelu (zwłaszcza tych polskojęzycznych) o najciekawszych pracach ukazujących się drukiem nad Wisłą. Przykładem tego jest np. artykuł zatytułowany: „Przeszkodnicy" z Krakowa, opublikowany na łamach telawiwskiego „Od Nowa"26; stanowi on recenzję książki Jana Pachońskiego Drukarze, księgarze i bibliofile krakowscy 1750-1815 27. Pomocna dla Löwa okazała się słynna „Księgarnia Polska” w Tel Awiwie, która mieściła się w podziemnym pasażu przy ulicy Allenby $94^{28}$. Należała do Ady i Edmunda Neusteinów. W powszechnym obiegu przyjęła się nazwa „Księgarnia Neusteinów”. W dobie komunizmu była to bodaj najlepiej zaopatrzona w polskie wydawnictwa księgarnia znajdująca się poza granicami Polski.Zresztą pod względem ilości i jakości dostępnych w niej tytułów mogła śmiało konkurować z większą częścią księgarni funkcjonujących w Polsce. Jeśli zaś uwzględnimy to, że w księgarni tej można było swobodnie nabyć książki

wypowiedział się na ten temat dla lokalnych mediów w Białymstoku. W serwisie Poranny.pl czytamy: „Białystok ma bardzo duże znaczenie dla historii i kultury społeczności żydowskiej - podkreśla Ryszard Loew, który w ostatnich dniach gościł w naszym mieście. Żydzi byli bardzo liczną grupą w przedwojennym społeczeństwie. Stąd pochodzi też bardzo wielu znanych i zasłużonych uczonych izraelskich. Ten publicysta, bibliograf, wydawca i krytyk literacki od wielu lat współpracuje z białostocką polonistyką. Podkreśla, że jest bardzo zaprzyjaźniony z jej pracownikami, bardzo ceni ich pracę i osobiste kontakty z nimi. Wubiegłym roku uhonorowany został medalem Zasłużony dla Uniwersytetu. [...] Wykonałem taki gest, żeby pomóc zarówno pedagogom, jak i uczącym się kultury i literatury na białostockim uniwersytecie - mówi Ryszard Loew. - Sądzę, że moja biblioteka okaże się tu użyteczna. [...] W testamencie zapisana też została pewna kwota na zrealizowanie tej darowizny", Biblioteka uniwersytecka wzbogaci się o pięć tysięcy książek (1.05.2013), http://www.poranny.pl/wiadomosci/bialystok/art/5531644,biblioteka-uniwersytecka-wzbogaci-sie-o-piec-tysiecy-ksiazek,id,t.html (dostęp: 11.12.2016). Wyd.z dn. 8.01.1963. Wydawnictwo Literackie, Kraków 1962.

Zob. R. Löw „Księgarnia Polska” (Edmund Neustein 1917-2001), "Archiwum Emigracji. Studia Szkice - Dokumenty" 2002, z. 4, s. 277-278. Por. tegoż Końcówki. Rzecz o polskich księgarzach wTel Awiwie, "Zeszyty Literackie" 1994 nr 46, s. 145-150. 
zakazane w PRL, to trzeba ją uznać za bezkonkurencyjną. Wedle deklaracji samego Löwa odwiedzał ją codziennie, nieraz nawet kilkakrotnie. Albowiem w „Księgarni Neusteinów” nie tylko zamawiano, kupowano i wypożyczano książki, ale także długo i namiętnie o nich dyskutowano. Przychodzono tutaj również po najnowsze egzemplarze prasy polskojęzycznej wydawanej w Izraelu ${ }^{29}$. Do wyjątków należały dni, w które Löw nie odwiedzał Neusteinów, najczęściej było to spowodowane tym, że przebywał poza Tel Awiwem ${ }^{30}$.

Wielką zaletą twórczości naukowej Löwa jest to, że została podbudowana autopsją. Przybliżył nam wiele sylwetek ludzi pióra, zasłużonych dla kultury polskiej i izraelskiej. Przygotowane przez niego obrazy nie są statyczne. Historyk musi ważyć na to, by skreślone przez niego portrety były dynamiczne. Nie chodzi przecież o to, by - posłużę się językiem obrazowym - przedstawić martwe motyle zamknięte w pudełku lub w gablotce za szklaną szybką. Prawdziwą sztuką jest zaprezentować je w pełnej okazałości, w takiej pozie, jaką przyjęły podczas lotu. Löw opanował tę sztukę do perfekcji. Po części przysłużył się do tego fakt, że bardzo często opisywane postaci znał osobiście, a przynajmniej z opowieści przyjaciół. Interesujące, że nie popełnił przy tym grzechu hagiografii. Nawet te prace Löwa, które traktują o jego najbliższych przyjaciołach czy o ludziach wywodzących się ze środowiska, które współtworzył, zachowują obiektywizm i głębokie pokłady faktografii. Biografistykę Löwa możemy (najprościej) podzielić na dwie kategorie: publicystyczną i naukową. Do pierwszej z nich zaliczymy np. krótkie teksty na temat: Wilhelma Falleka $^{31}$, Karola Dresdnera ${ }^{32}$, Łucji Gliksman ${ }^{33}$, Józefa Andrzeja Gierowskiego $^{34}$, czy Chone Szmeruka ${ }^{35}$. Kategorię naukową współtworzą m.in.: Helena

29 R. Löw Ostatki polskie. Rzecz o izraelskiej prasie w języku polskim, „Zeszyty Literackie” 1994 nr 48, S. 152-155; tegoż Ostatki polskie. Rzecz o izraelskiej prasie w języku polskim, cz. II: Tygodniki ialmanachy, "ZZeszyty Literackie" $1995 \mathrm{nr}$ 49, s. 141-145. Temat prasy polskojęzycznej w Izraelu szeroko omówiła E. Kossewska w pracy Ona jeszcze mówi po polsku, ale śmieje się po hebrajsku. Partyjna prasa polskojęzyczna a integracja kulturowa polskich Żydów w Izraelu (1948-1970), Wydawnictwa UW, Warszawa 2015.

Rozmowa Ł.T. Sroki z Ryszardem Löwem, przeprowadzona w Tel Awiwie, 22.11.2016 roku. (6250).

R. Loew Przypomnienie Karola Dresdnera, „Nowiny Kurier” 11.04.1975 nr 85 (6187).

R. Löw Świadek naszych tęsknot, "Nowiny Kurier" 30.01.2004, s. 13-14. 
Hecker. Zapomniany historyk Żydów polskich ${ }^{36}$, O pani Łucji, której już nie ma. Łucja Pinczewska-Gliksman (1913-2002) ${ }^{37}$, Rzecz o Berku Neumanie - drukarzu wileńskim ${ }^{38}$, Ukochała obydwa narody: Dora Kacnelson 1921-2003-2013 ${ }^{39}$. Koniecznie też należy zwrócić uwagę na artykuł Znaki obecności ${ }^{40}$, dotyczący Stanisława Wygodzkiego. Jest to nie tylko tekst znakomity, jeśli chodzi o jego formę, ale także - co nie mniej istotne - poświęcony ważnemu, acz raczej zapomnianemu już w Polsce pisarzowi. Ukazał się w Zeszycie Pamięci o Stanisławie Wygodzkim. To starannie zredagowana (w języku polskim) książka, wydano ją w 1992 roku w Tel Awiwie, niestety w niedużym nakładzie, $\mathrm{w}$ formie maszynopisu powielonego. Przez to w Polsce generalnie pozostała niezauważona.

Löw ma zwyczaj przeplatania narracji naukowej z osobistymi wywodami i wspomnieniami. Dzięki temu możemy odebrać bezcenną lekcję na temat kulis życia i pracy jego samego oraz innych ludzi nauki i kultury. Przykładem tego jest tekst zatytułowany Zapomniany historyk wileński, traktujący o Pinchasie Konie. Zaczyna się on w następujący sposób:

Podczas wizyty w redakcji „Polskiego Słownika Biograficznego” przed paroma laty w Krakowie usiłowałem sprawdzić, dlaczego w odpowiednim tomie tego monumentalnego wydawnictwa nie umieszczono biogramu historyka wileńskiego Pinchasa Kona. Skontrolowanie założonej w swoim czasie kartoteki ujawniło, że biogram Kona miał napisać prof. Artur Eisenbach z Warszawy, jednakże ani w przewidzianym terminie, ani później go nie nadesłał. Tak się złożyło, że po kilku dniach spotkałem prof. Eisenbacha w Warszawie. Od razu więc zagadnąłem go o nie dostarczony »Słownikowi « życiorys Kona. Uśmiechnął się smutno i bezradnie rozłożył ręce. - Ja Kona nawet nieźle znałem - powiedział w zadumie widywałem go niejednokrotnie, kiedy zaś zasiadłem do pisania, okazało się, że tak naprawdę - nic o nim nie wiem... ${ }^{41}$

„Miasteczko Poznań" 2016 nr 1 (24), S. 164-169. R. Löw był siostrzeńcem Heleny Hecker.

"Archiwum Emigracji. Studia - Szkice - Dokumenty" 2002/2003 nr 56, s. 335-337.

"Teksty Drugie" 2012 nr 6, s. 373-381.

Pierwodruk: „Bibliotekarz Podlaski” 2013 nr 1; tekst ukazał się również w tomie: Literackie podsumowania, polsko-hebrajskie, polsko-izraelskie..., s. 114-132. 
Tego rodzaju wstępy wyznaczają specyficzny styl pisarski Löwa i - jak wspomniałem - są bardzo cennym źródłem wiedzy. Znamienne dla pisarstwa Löwa są również umiejętnie wkomponowane w fachową opowieść jego prywatne opinie, poglądy i przemyślenia. W artykule Zdarzenia wśród książek znajduje się np. taki ustęp:

Bibliofile, posiadacze wytrwale i pieczołowicie gromadzonych bibliotek szczególnym pietyzmem otaczają zazwyczaj książki opatrzone odręcznym podpisem czy dedykacją autora. Książka taka bowiem od innych egzemplarzy tej samej edycji, z którymi wspólnie opuściła prasę drukarską, różni się znacznie zmniejszoną anonimowością, adresatem ściśle wyznaczonym przez twórcę, z którym łączą go związki koleżeństwa, przyjaźni lub na opinii którego szczególnie mu zależy. ${ }^{42}$

Oryginalny styl pisarski Löwa sprawił, że jego teksty są w dwójnasób wartościowe. Po pierwsze, przynoszą rzeczową analizę naukową życia i twórczości ważnych a nie zawsze znanych osobistości nauki, literatury i sztuki. Po drugie, w tekstach i w wywiadach Löwa znajduje się wiele cennych uwag dotyczących życia prywatnego ludzi pióra i kultury. Te informacje mają często kapitalne znaczenie dla zrozumienia ludzkich dramatów i zawiłości, które przecież nie pozostały bez znaczenia dla życiowej i zawodowej drogi konkretnych osób. Przykładem jest wypowiedź Löwa na temat Stanisława Jerzego Leca (1909-1966). Lec przyszedł na świat we Lwowie w rodzinie tworzonej przez Adelę z domu Safrin oraz barona Benona de Tusch-Letza. Kształcił się we Lwowie oraz w Wiedniu. Jeszcze przed II wojną światową zadebiutował jako poeta, ale zapamiętany został głównie jako niezmiernie błyskotliwy i pełen osobliwego poczucia humoru satyryk i aforysta (autor tłumaczonego na kilkanaście języków tomu Myśli nieuczesane, 1957). Po wojnie pracował w ambasadzie polskiej w Wiedniu (1946-1950). W 1950 roku na krótko wyjechał do Izraela, o czym wiemy niestety niewiele. Rąbka tajemnicy uchylił właśnie Löw, podczas rozmowy z Marią Lewińską:

Otóż Lec przyjechał do Izraela z żoną i dwojgiem dzieci. [...] Od razu po przybyciu [...] zorientował się, że to nie jest dla niego, że on nie potrafi żyć poza Polską. Nie przyjmował żadnej pracy, jaką mu proponowali rozliczni przyjaciele, a która planowanemu powrotowi do Polski mogłaby

R. Loew Zdarzenia wśród książek, „Nowiny Kurier” 4.04.1975 nr 79 (6181). 
przeszkodzić. [...] Przyjął pracę stróża nocnego na budowie. Pamiętam, że go odwiedziłem raz czy dwa, on nawet sobie chwalił tę pracę, ale to była dobra mina do złej gry, a może nawet zła mina do złej gry. Mówił: tu stawiają takie budki, podprowadzają prąd, a ja sobie siedzę i piszę. To może wtedy powstały te wspaniałe, pełne tęsknoty za Polską liryki, które się złożyły na później wydany zbiorek pt. „Rękopis jerozolimski”. Lec zniknął w roku pięćdziesiątym drugim, ale zapłacił za to rozbiciem rodziny: rozwiódł się, zostawił tutaj żonę i córkę i wrócił do Polski z synem. Założył tam nową rodzinę. ${ }^{43}$

Zaryzykuję pewną tezę. Otóż w mojej ocenie do okresu przemian społeczno-ustrojowych w Polsce główną rolą Ryszarda Löwa było inicjowanie polskiego życia naukowego i kulturalnego w Izraelu. Później jego największym wyzwaniem stało się przybliżenie owoców tej kilkudziesięcioletniej pracy mieszkańcom Polski. Stało się to możliwe, ponieważ w związku z upadkiem komunizmu ponownie mógł odwiedzać Polskę. Poza tym nasz kraj na nowo otwarł się na świat. Nastąpił renesans zainteresowania historią i kulturą Żydów polskich, także tych żyjących w Izraelu. Zarazem w samym Izraelu chwilowo spadło zainteresowanie Polską (i polskością), gdyż wielu urodzonych w niej Żydów dożyło już swoich ostatnich dni, a ich potomkowie wrośli w społeczeństwo izraelskie. Inna rzecz, że obecnie w Izraelu znów wzrasta zainteresowanie krajem nad Wisłą; powodów tego jest wiele, ale pozwalam sobie nie rozszerzać tego wątku z tej racji, że wykracza on poza tematykę niniejszego opracowania. Owszem, nietrudno o polemikę z moją tezą. Wszak Löw już w latach 1957-1981 pracował jako korespondent Pracowni Bibliograficznej Instytutu Badań Literackich w Poznaniu. Aczkolwiek efekty jego pracy choć poważne, znane były tylko elitarnemu gronu badaczy literatury.

Niestety niewiele wiemy o szczegółach pracy Löwa na stanowisku prezesa Związku Autorów Piszących po Polsku w Izraelu (1987-1988, następnie od 1990 roku) oraz w roli redaktora rocznika literackiego i historycznoliterackiego „Kontury”. Wydawano je w języku polskim w latach 1988-2006 w Tel Awiwie (łącznie szesnaście numerów) ${ }^{44}$. Pierwsze ich dwa numery (19881989) ukazały się staraniem Renaty Jabłońskiej, Anieli Jasińskiej i Anny

43 M. Lewińska Przechowane słowa, Instytut Polski w Tel Awiwie, Tel Awiw 2008, s. 10-11.

44 Zob. R. Löw Kontury. Pismo - Autorzy - Tematy - Recepcja, w: M. Lewińska Przechowane słowa, s. 68-93. Zob. również: K. Famulska-Ciesielska, J.S. Żurek Literatura polska w Izraelu. Leksykon, Austeria, Kraków-Budapeszt 2012, s. 107. 
Kadary. Trzeci numer (1992) zredagowali: Jael Shalitt i Natan Gross. Później odpowiedzialność za pismo przejął Ryszard Löw (przy numerze czwartym /1993/ uzyskał pomoc Krystyny Bernard i Łucji Gliksman) ${ }^{45}$. Dokładne naświetlenie tej kwestii stanowiłoby nie tylko ważne dopełnienie jego biografii. W ten oto sposób postawilibyśmy dodatkową kreskę do portretu zbiorowego społeczności Żydów polskich w Izraelu. Prawimy tu o grupie różnorodnej, współtworzonej przez wiele wybitnych indywidualności, skutecznie a nieraz wręcz przebojowo realizującej własne aspiracje życiowe i zawodowe. Kluczową rolę w tym środowisku odegrali inteligenci, ale przecież nie była to grupa jednorodna. Nawet w tak wąskiej formacji jak Związek Autorów Piszących po Polsku w Izraelu, dały o sobie znać różne stanowiska i poglądy. W 1991 roku wypowiedział się na ten temat Ryszard Löw w wywiadzie udzielonym Andrzejowi Koziołowi:

Pewna grupa osób uważa się za autorów piszących po polsku, bo jest to język, który znają. W rzeczywistości jednak celują w izraelskiego czytelnika, poprzez tłumaczenia chcą się dostać na rynek hebrajski. Po prostu uważają się za tak silnie związanych z Izraelem, że w żaden sposób nie chcą czuć się związani z macierzystą kulturą, a moim zdaniem macierzystą kulturą dla każdego pisarza jest kultura języka, w którym pisze. Drugą tendencję reprezentowałem ja i - jak się okazało - znalazłem się w mniejszości. Chodziło mi o stworzenie zinstytucjonalizowanego polskiego życia literackiego w Izraelu poprzez wieczory autorskie, spotkania, przyjmowanie coraz częściej przyjeżdżających autorów polskich z kraju i z Zachodu. Chodziło mi też o nawiązanie kontaktów z życiem kulturalnym w Polsce, co w pewnej - może nawet dużej - mierze udało się. ${ }^{46}$

Przywołany tutaj fragment rozmowy, która ukazała się na łamach „Dziennika Polskiego", daje nam wgląd w meandry środowiska polskojęzycznych pisarzy w Izraelu. Bardziej dogłębne poznanie Związku Autorów Piszących po Polsku w Izraelu pozwoliłoby wprowadzić do historiografii wiele nowych ustaleń naukowych. Przy czym z pola widzenia nie powinniśmy utracić także tych osób, które z różnych powodów unikały zinstytucjonalizowanych form aktywności.

Rozmowa z Ryszardem Löwem, w: M. Lewińska Analfabeci z wyższym wykształceniem, Austeria, Kraków-Budapeszt 2016, s. 25. 
Historia polskojęzycznej prasy i twórczości literackiej w Izraelu pozwala lepiej poznać nie tylko stojących za nią Żydów polskich, ale także prowadzoną wobec nich (jak też wobec innych grup etnicznych) politykę absorpcyjną ze strony rządu niepodległego Izraela. Władze „młodego” państwa miały ambicje szybkiego zespolenia wszystkich grup, przybywających z różnych zakątków świata. Wnet okazało się, że musi to być proces bardziej zniuansowany i rozłożony w czasie. Wcześniejsze rachuby zostały bowiem skonfrontowane z realiami, o których wspomina Löw: „[...] przyjeżdżali nie tylko młodzi, lecz także ludzie pięćdziesięcio-i sześćdziesięcioletni, a nawet starsi, dla których kontakt ze współczesnym Izraelem bez takich gazet był absolutnie niemożliwy. Przyjaciel moich rodziców mawiał, że pracuje w pewnej instytucji już od pięciu lat i nie jest w stanie zapamiętać jej hebrajskiej nazwy" ${ }^{47}$. Notabene, gdy rozważa się politykę informacyjną i edukacyjną rządu izraelskiego (a wcześniej formacji syjonistycznych), nie sposób pominąć wątku wykorzystania przekładów wybranych dzieł literatury polskiej na język hebrajski. Wlicznych pracach Löwa znajdziemy sporo informacji na temat tego, które dzieła tłumaczono, dlaczego i z jakim skutkiem.

W słowie podsumowania wracam do zastosowanej w tytule gry słów: „Ryszard Löw jakiego (nie) znamy”. Otóż w środowisku literaturoznawców, historyków literatury, historyków czy judaistów Ryszard Löw jest postacią powszechnie rozpoznawalną. Na ogół jednak pod jego adresem kierowane są uzasadnione, ale nader ogólne i powtarzane po raz wtóry słowa zachwytu. Brakuje jak dotąd kompetentnego studium dotyczącego jego twórczości. Nadto oczekiwana jest fachowa biografia, która odsłoniłaby kulisy jego rozległej działalności jako publicysty, redaktora, wydawcy, animatora polskiego życia społeczno-kulturalnego w Izraelu, współpracownika polskich instytucji nauki i kultury. Oczywiście przedłożona przeze mnie praca również nie wypełnia tej luki. Cele, które sobie tutaj założyłem, są trzy. W pierwszej kolejności chodziło o to, by nowej grupie czytelników przybliżyć sylwetkę i dorobek Ryszarda Löwa oraz sformułować i uzasadnić postulat przygotowania nowoczesnych studiów poświęconych zarówno jemu jak, i jego twórczości. Kolejnym zadaniem było zebranie możliwie pełnej bibliografii jego prac, co jest o tyle istotne, że może wydatnie pomóc w realizacji dwóch pierwszych zadań.

47 M. Lewińska Analfabeci z wyższym wykształceniem, s. 21. 


\section{Abstract}

\section{Łukasz Tomasz Sroka}

PEDAGOGICAL UNIVERSITY OF CRACOW

The Ryszard Löw We (Do Not) Know

In academic circles Ryszard Löw has been valued as a Polish and Israeli journalist, bibliographer, publisher, literary critic, promoter of culture and reliable researcher, but younger scholars in literature, history and Jewish studies are losing interest in his work. Löw's achievements as a writer and organiser are part of a wide range of activities of the Polish emigration after 1945, esp. the community of Polish Jews living in Israel. Löw's work, however, never positioned him within one particular academic field, nor was he ever employed by an academic institution. Löw, who has collected information on the most scattered works of literature and literary scholarship, was also published mostly in niche publications across Europe. There is no successor to Löw in Israel, which is why his work of several decades must urgently be returned to circulation.

\section{Keywords}

Ryszard Löw, Polish-language literature in Israel, Jewish history, Polish-Jewish relations, Polish-Israeli relations 